\title{
A New, Wide Host-range, Temperate Bacteriophage (R4) of Streptomyces and its Interaction with some Restriction-Modification Systems
}

\author{
By K. F. CHATER AND A. T. CARTER \\ John Innes Institute, Colney Lane, Norwich NR4 7UH
}

(Received 5 March 1979)

\begin{abstract}
A new temperate phage, R4, of Streptomyces was isolated from soil on a restrictiondeficient mutant of $S$. albus G. In its morphology, adsorption properties and growth kinetics $\mathrm{R} 4$ resembled other temperate phages of Streptomyces though its requirements for $\mathrm{Ca}^{2+}$ and $\mathrm{Mg}^{2+}$ were higher than usual. It was unable to form plaques above $34.5{ }^{\circ} \mathrm{C}$. R4-mediated transduction was not detected. Unlike other Streptomyces temperate phages, R4 had a wide host-range, which correlated better with the absence of detectable class II restriction enzymes than with conventional taxonomic divisions. Many of the sensitive strains [but not, apparently, S. coelicolor A3(2)] could be lysogenized.

With the wild-type R4, plaques were obtained on $S$. albus $\mathrm{G}$ only after growth on a restriction-deficient, modification-proficient mutant, and then only at a very low efficiency of plating. All of these plaques were of a mutant type (R4G) which (unlike the parental $\mathrm{R} 4$ phage) showed conventional patterns of restriction-modification in the $S$. albus $\mathrm{G}$ (SalGI) and S. albus P (SalPI) systems. R4G mutants, but not R4, were sensitive to a restrictionmodification system present in two $S$. rimosus strains (2251 and NRRL 2234). DNA from SalGI-unmodified (but not from modified) R4 or R4G was cleaved by SalGI into more than 30 fragments (mean size 1.35 kilobases; summed molecular weight $30.02 \times 10^{6}$ ). R4 DNA was cleaved at one site by EcoRI, at one site by SalPI ( $\equiv P$ st I), and not at all by HindIII or BamHI.
\end{abstract}

\section{INTRODUCTION}

The most detailed study of a temperate bacteriophage of Streptomyces has been of $\phi \mathrm{C} 31$, which originated from Streptomyces coelicolor A3(2) where it is apparently normally present as a defective prophage (Lomovskaya et al., 1971). A group of temperate phages of $S$. coelicolor A3(2), homoimmune to each other but heteroimmune with respect to $\phi \mathrm{C} 31$, was isolated from soil by Dowding \& Hopwood (1973), and one of these (VP5) has been investigated further (Chater \& Sykes, 1976). A third immunity group of S. coelicolor temperate phages is represented by $\phi 448$ (isolated by N. D. Lomovskaya, Moscow) and S14, recently isolated in this laboratory (C. Stuttard \& K. F. Chater, unpublished results). All three groups share the feature of relatively narrow host-range, while most virulent phages of $S$. coelicolor isolated from soil formed plaques on most wild-type Streptomyces spp. (Dowding, 1972).

We report here the isolation from soil of a temperate Streptomyces bacteriophage (R4) which represents a fourth immunity group and has an unusually wide host-range. Some features of R4 relevant to our interest in restriction in Streptomyces are described. 


\section{METHODS}

Strains and microbiological techniques. The wild-type strains used are listed in Table 2. Complete medium (CM), minimal medium (MM), the growth of streptomycetes and the preparation of spore suspensions were as in Hopwood (1967). Adsorption, one-step growth experiments, propagation and assay of bacteriophages were done with Difco-Bacto nutrient broth (NB) or nutrient agar (NA) as described by Dowding (1973), except that $25 \mathrm{~mm}-\mathrm{Ca}\left(\mathrm{NO}_{3}\right)_{2}$ and $10 \mathrm{~mm}-\mathrm{MgSO}_{\downarrow}$ were added for best results with $\mathrm{R} 4$ (see Results), and adsorption prior to one-step growth experiments was done in the presence of $0.1 \mathrm{~mm}-\mathrm{KCN}$ (Chater \& Sykes, 1976).

$D N A$. The preparation of phage DNA, its digestion with restriction enzymes and subsequent analysis by agarose gel electrophoresis were as in Chater \& Wilde (1976) and Chater (1977). Guanosine plus cytosine content of phage DNA was calculated from buoyant density in $\mathrm{CsCl}$ density gradients as described by Bibb et al. (1977). Internal standards were coliphage $\lambda$ DNA (49 mol \% guanosine plus cytosine; MacHattie \& Thomas, 1968) and $S$. albus G DNA (73 mol \% guanosine plus cytosine; K. Chater, unpublished data).

Restriction enzymes. SalGI was prepared as in Chater \& Wilde (1976) and SalPI as in Chater (1977); EcoRI, HindIII and BamHI were from Miles Laboratories. Examination of cell-free extracts of various wildtype streptomycetes for class II restriction enzyme activity was done as in Chater \& Wilde (1976) using $\lambda$ DNA as substrate unless stated otherwise.

Electron microscopy. Phage particles sedimented by centrifugation at $40000 \mathrm{~g}$ for $90 \mathrm{~min}$ were resuspended in $200 \mathrm{~mm}$-sodium acetate and negatively stained with uranyl acetate before examination in a Siemens Elmiskop electron microscope.

\section{RESULTS}

\section{Storage and assay conditions}

R4 was first seen as a turbid plaque obtained by plating a nutrient broth extract of local soil on strain J1074, a mutant of Streptomyces albus G defective in the SalGI restriction and modification system (Chater \& Wilde, 1976). R4 showed little loss in viability when stored for $2 \mathrm{~h}$ in nutrient broth, distilled water, or $10 \mathrm{~mm}$-Tris/acetate $\mathrm{pH} 7.0$ and $4 \mathrm{~mm}-\mathrm{Ca}\left(\mathrm{NO}_{3}\right)_{2}$, but lost about $50 \%$ viability after $24 \mathrm{~h}$ in T2 buffer (Hershey \& Chase, 1952) or SM buffer (Chater \& Wilde, 1976). R4 was slowly inactivated by the addition of $1 \%$ chloroform (survival $3 \times 10^{-3}$ at $24 \mathrm{~h}$ ) and was sensitive to $15 \mathrm{~mm}$-sodium citrate (in $150 \mathrm{~mm}-\mathrm{NaCl}$, $\mathrm{pH} 8.0)$ (1\% survival after $10 \mathrm{~min}$ at room temperature).

The efficiency of plating (e.o.p.) and plaque morphology of R4 were considerably influenced by the divalent cation content of the medium (Fig. 1). The highest e.o.p. was obtained with $25 \mathrm{~mm}-\mathrm{Ca}\left(\mathrm{NO}_{3}\right)_{2} . \mathrm{MgSO}_{4}$ was less effective: the highest e.o.p. (with $10 \mathrm{~mm}$ $\mathrm{MgSO}_{4}$ ) was about $40 \%$ of that obtained with $25 \mathrm{~mm}-\mathrm{Ca}\left(\mathrm{NO}_{3}\right)_{2}$. Addition of $10 \mathrm{~mm}-\mathrm{MgSO}_{4}$ slightly increased the e.o.p. with a range of $\mathrm{Ca}\left(\mathrm{NO}_{3}\right)_{2}$ concentrations and resulted in much larger plaques. All the experiments described below were done with $25 \mathrm{~mm}-\mathrm{Ca}\left(\mathrm{NO}_{3}\right)_{2}$ and $10 \mathrm{mM}^{-\mathrm{MgSO}_{4}}$.

\section{Morphology of $\mathrm{R} 4$}

In overall dimensions and appearance R4 was similar to bacteriophage lambda (Kellenberger \& Edgar, 1971), having a head with a hexagonal outline measuring $64 \mathrm{~nm}$ both lengthways and laterally and a laterally striated flexible tail of $190 \mathrm{~nm}$ length and $12.5 \mathrm{~nm}$ diameter (Fig. 2). No specialized structures at either end of the tail were seen.

\section{Adsorption and one-step growth curve}

Adsorption to freshly germinated spores of $\mathrm{J} 1074$ was somewhat more efficient $(95 \%$ adsorption in $35 \mathrm{~min}$, adsorption constant $1.7 \times 10^{-9} \mathrm{ml} \mathrm{min}^{-1}$ ) than adsorption of other Streptomyces phages to spores of $S$. coelicolor A3(2). The extent to which this was a function of the host was not determined.

Using a clear-plaque mutant of R4 (R4c1; see below) the one-step growth kinetics (Fig. 3) were similar to those for temperate phages $\phi \mathrm{C} 31$ (Lomovskaya et al., 1972) and VP5 (Chater \& Sykes, 1976) and for virulent phages VP11 (Dowding, 1973) and VP12 (K. F. Chater, 


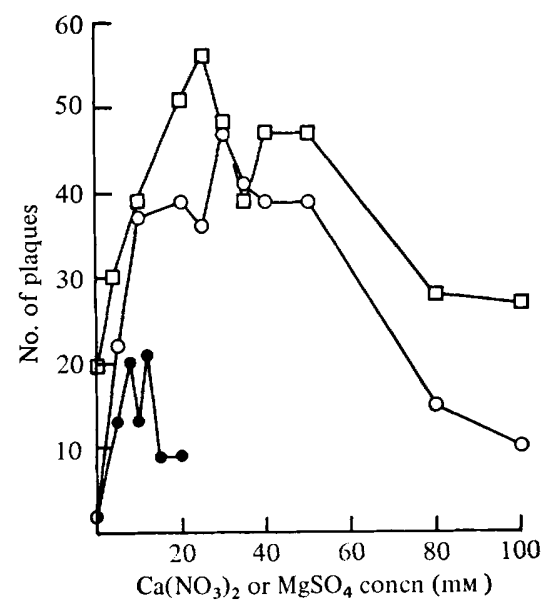

Fig. 1. Effect of $\mathrm{Mg}^{2+}$ and $\mathrm{Ca}^{2+}$ on the efficiency of plating of R4 on $S$. parvulus ATCC 12434: $\bigcirc, \mathrm{Ca}\left(\mathrm{NO}_{3}\right)_{2} ; 0, \mathrm{MgSO}_{4} ; \square, 10 \mathrm{mM}-\mathrm{MgSO}_{4}$ plus $\mathrm{Ca}\left(\mathrm{NO}_{3}\right)_{2}$ as indicated.

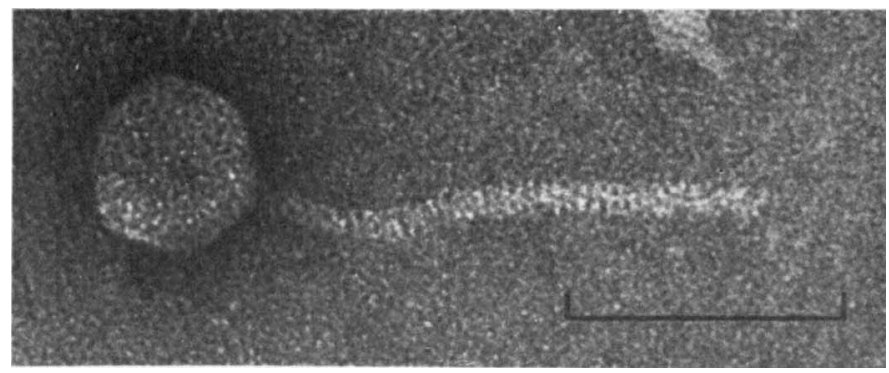

Fig. 2. Electron micrograph of bacteriophage R4 negatively stained with uranyl acetate. Bar marker represents $100 \mathrm{~nm}$.

unpublished results). The latent period was 45 to $60 \mathrm{~min}$ and the burst size was 10 to 50 . Similar results were obtained with either J1074 or $S$. parvulus as host.

\section{Heat sensitivity of $\mathrm{R} 4$ development}

$\mathrm{R} 4$ did not form plaques on $\mathrm{J} 1074$ or $S$. parvulus at temperatures above $34.5{ }^{\circ} \mathrm{C}$, although both hosts grew well at temperatures several degrees higher. This was not due to temperaturesensitivity of the intact particle, since no loss of viability was observed when R4 was maintained at $37^{\circ} \mathrm{C}$ for $100 \mathrm{~min}$. Modified one-step growth experiments (Fig. 4) incorporating temperature shift-up indicated that phage development became heat-resistant only late in the latent period ( 30 to $35 \mathrm{~min}$ ). Mutants able to form plaques at $35 \cdot 5^{\circ} \mathrm{C}$ were not found either spontaneously (frequency less than $2.5 \times 10^{-9}$ ) or after ultraviolet irradiation to $1 \%$ survival (frequency less than $4 \times 10^{-5}$ ).

\section{$\mathrm{R} 4$ is a temperate phage}

Upon extensive purification on CM containing $10 \mathrm{mM}$-sodium citrate (which should have greatly reduced the amount of free phage), cultures derived from the turbid centres of R4 plaques on $\mathrm{J} 1074$ often proved to be completely resistant to R4 infection. To test whether these strains had become lysogenic for R4, spore suspensions washed in $10 \mathrm{~mm}$-sodium citrate were plated at various dilutions on $\mathrm{CM}$ for viable counts and on NA base plates in soft agar overlays containing $\mathrm{J} 1074$ indicator spores to detect the presence of plaqueforming units. Colony counts on CM were about 100 -fold higher than plaque counts. 


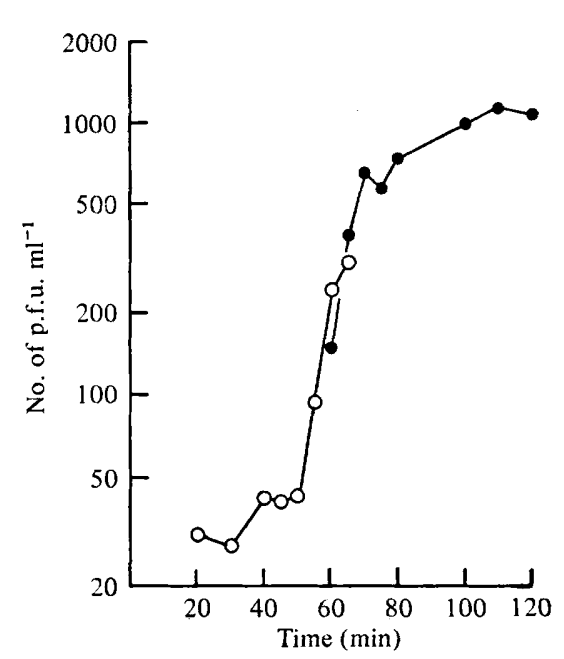

Fig. 3

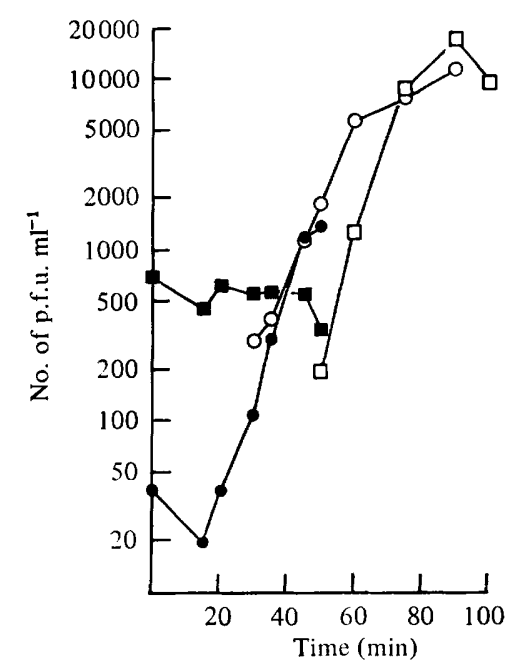

Fig. 4

Fig. 3. One-step growth curve on S. parvulus ATCC 12434 of a clear-plaque mutant (R4c1) of bacteriophage R4. Counts of plaque-forming units (p.f.u.) derived from plating samples from an undiluted fiask $(O)$ and from a flask containing a 10 -fold dilution of the infected cells (O) are shown.

Fig. 4. Modified one-step growth curve incorporating temperature shifts. A one-step growth experiment $(\square, \square)$ was carried out at $30^{\circ} \mathrm{C}$ (using J1074 as host) as in Fig. 3. In addition, samples were transferred to $\mathrm{NB}$ at $37^{\circ} \mathrm{C}$ at intervals, incubated until $100 \mathrm{~min}$ after the start of the experiment, and then rapidly plated to assay plaque-forming units $(O, O)$. Results from plating $10^{-1}$ dilutions $(\square, O)$ and $10^{-2}$ dilutions $(\square, \bigcirc)$ are shown. The presence of low counts in the early samples subjected to temperature shift was attributable to the presence of a low level of unadsorbed phage.

However, most colonies could be shown to contain free phage by replication to NA followed $24 \mathrm{~h}$ later by overlaying with soft agar containing J1074 indicator. Thus the colonies were lysogenic and R4 was therefore a temperate phage. Unlike other temperate phages of Streptomyces, clear-plaque mutants of R4 were rare: after ultraviolet irradiation to $1 \%$ survival, none was found among 92000 survivors. However, a single spontaneous clearplaque mutant (R4cl) was obtained during routine platings. R4cl was unable to form plaques on R4 lysogens.

\section{Attempted transduction with $\mathrm{R} 4$}

An R4 mutant (R4G2; see below) propagated on strain J1074 was used as a potential transduction agent at multiplicities of infection of 1 to 20 with germinated spores of a restriction-defective mutant of S. albus G, requiring adenine and arginine plus uracil (Ade ${ }^{-}$Aur ${ }^{-}$) for growth, in a number of experiments involving continued incubation of the mixture in NB before spreading on media (MM plus adenine, MM plus arginine plus uracil) selecting Aur ${ }^{+}$or Ade transductants, or on CM to allow a round of non-selective growth before harvesting spores and plating them on selective media. In other experiments, germinated spores were spread on selective media and phage was then added. No evidence of transduction was obtained in any of these experiments.

\section{Host-range}

Of 36 wild-type Streptomyces spp. tested, plaques were formed initially on 14 with quite high efficiency, on four with much lower efficiency and were not detected with 18 (Tables 1 and 2). No plaques were seen with Nocardia mediterranei (ATCC 13685) or Corynebacterium glutamicum (GAB 18000). 


\section{Table 1. Interaction of unmodified wild-type $\mathrm{R} 4$ phage with sensitive Streptomyces strains}

Efficiency of plating (e.o.p.) on putative lysogens is given in relation to that on the non-lysogenic parent strain. The column 'p.f.u./c.f.u.' gives the ratio of plaque numbers with the non-lysogen as indicator to the number of colony forming units on $C M . R^{-}$and $R^{+}$refer to restriction deficiency and proficiency, respectively.

\begin{tabular}{|c|c|c|c|c|c|}
\hline & \multicolumn{2}{|c|}{ Test of putative lysogens } \\
\hline Strain & R4 e.o.p. & $\begin{array}{c}\text { Plaque } \\
\text { morphology }\end{array}$ & $\begin{array}{l}\text { Ease of isolation of } \\
\text { lysogens from plaques }\end{array}$ & R4 e.o.p. & $\overline{\text { p.f.u./c.f.u. }}$ \\
\hline S. albus G R- J1074 & $1 \times 10^{0}$ & Large & Easy & $<2 \times 10^{-3}$ & $1 \times 10^{-2}$ \\
\hline S. albus $\mathbf{G}^{+}$ & $>1 \times 10^{-8}$ & - & -- & - & - \\
\hline S. albus P CMI 52766 & $1 \times 10^{-5}$ & Large & NT & -- & - \\
\hline S. antibioticus CUB 471 & $1 \times 10^{-3}$ & - & -- & - & -- \\
\hline S. azureus ATCC 14921 & $1 \times 10^{0}$ & Small & NT & -- & - \\
\hline S. coelicolor A3(2) & $1 \times 10^{-2}$ & Small & None detected & -- & - \\
\hline S. coelicolor (Müller) & $2 \times 10^{-7}$ & Medium & NT & - & - \\
\hline S. erythreus CUB 92 & $9 \times 10^{-1}$ & Small & Each plaque mixed & $<3 \times 10^{-4}$ & $1.5 \times 10^{-2}$ \\
\hline S. griseus CUB 294 & $8 \times 10^{-1}$ & Medium & Easy & $<3 \times 10^{-4}$ & $5 \times 10^{-2}$ \\
\hline S. griseus CUB 625 & $6 \times 10^{-1}$ & Small & Each plaque mixed & $<1 \times 10^{-2}$ & $4 \times 10^{-3}$ \\
\hline $\begin{array}{l}\text { 'S. hygroscopicus' } \\
\text { IMET } 20664\end{array}$ & $1 \times 10^{-1}$ & Small & None detected & - & - \\
\hline S. lividans 66 (Lomovskaya) & $1 \times 10^{0}$ & Large & Very rare & $<1 \times 10^{-8}$ & $5 \times 10^{-5}$ \\
\hline S. parvulus ATCC 12434 & $1 \times 10^{0}$ & Large & Each plaque mixed & $<2 \times 10^{-4}$ & $1 \times 10^{-3}$ \\
\hline S. rimosus NRRL 2234 & $1 \times 10^{-1}$ & Small & None detected & - & - \\
\hline S. rimosus 2251 & $1 \times 10^{-1}$ & Small & Easy & $<1 \times 10^{-2}$ & $5 \times 10^{-3}$ \\
\hline S. venezuelae CUB 104 & $6 \times 10^{-1}$ & Medium & Easy & $<2 \times 10^{-4}$ & $4 \times 10^{-3}$ \\
\hline $\begin{array}{l}\text { S. viridochromogenes } \\
\text { CUB } 539\end{array}$ & $4 \times 10^{-1}$ & Large & Each plaque mixed & NT & $1 \times 10^{-2}$ \\
\hline $\begin{array}{l}\text { S. viridochromogenes } \\
\text { CUB } 608\end{array}$ & $1 \times 10^{-3}$ & Small & NT & -- & - \\
\hline S. virginae ATCC 13161 & $1 \times 10^{\circ}$ & Small & Very rare & $<1 \times 10^{-8}$ & $<1 \times 10^{-8}$ \\
\hline Unidentified 1158 & $1 \times 10^{-1}$ & Small & NT & - & - \\
\hline
\end{tabular}

Most of the strains giving high e.o.p. could be lysogenized by $\mathrm{R} 4$, although the ease with which lysogens were obtained varied greatly (Table 1). We never were able to obtain lysogens of $S$. coelicolor A3(2): indeed, some derivatives of $S$. coelicolor A3(2) were very poor hosts for R4. This was independent of the status of the derivatives with respect to plasmids SCP1 and SCP2 (Hopwood et al., 1973; Bibb et al., 1977). We were unable reliably to score this difference in susceptibility by replica-plating, so that attempts to locate genes controlling it on the $S$. coelicolor linkage map failed.

A remarkable feature of the host-range of $\mathrm{R} 4$ is its independence of the host's taxonomic status (Table 2). Interestingly, however, among strains showing initial high sensitivity to R4, 0/6 tested had detectable class II restriction enzyme activity in cell-free extracts, whereas among those initially resistant to $\mathrm{R} 4,9 / 12$ tested showed class II restriction enzyme activity in extracts. In the case of $S$. albus $\mathrm{G}$, initial resistance to R4 was certainly due to restriction since R4 had a high e.o.p. on restriction-deficient mutants (e.g. J1074). Further work on the interaction of R4 with $S$. albus $\mathrm{G}$ is discussed in the following section.

The possible involvement of host-controlled restriction-modification systems in the low e.o.p. of R4 on S. coelicolor (Müller) and S. albus $\mathrm{P}$ was also examined. Phages soaked out from the rare plaques on each host had acquired high e.o.p. on the respective strains. This was retained after subsequent propagation on strain J1074, suggesting that either (i) hostrange mutants, perhaps with changed adsorption characteristics, had been selected or (ii) the DNA of the phages had originally possessed a single target for restriction by the respective hosts, and mutants lacking this target were being selected. In the case of S. albus $\mathbf{P}$ the latter hypothesis proved true (Chater \& Carter, 1978), the high apparent level of 


\section{Table 2. Sensitivity of various Streptomyces strains to R4}

The strains are arranged according to their taxonomic status (after Arai et al., 1976). Strains on which R4 or its mutant derivatives can form plaques, whatever the circumstances, are considered sensitive (see Table 1 and text for further details).

\begin{tabular}{|c|c|c|}
\hline Group & Sensitive to $\mathbf{R} 4$ & Resistant to $\mathbf{R} 4$ \\
\hline Rectiflexibiles, Yellow & $\begin{array}{l}\text { S. coelicolor (Müller) } \\
\text { S. griseus CUB } 294 \\
\text { S. griseus CUB } 625\end{array}$ & $\begin{array}{l}\text { S. coelicolor (Müller) UC5240 } \\
\text { S. griseus CUB } 609 \\
\text { *S. griseus ATCC } 23345 \\
\text { S. griseus ATCC } 10137\end{array}$ \\
\hline Rectiflexibiles, Grey & S. antibioticus CUB 471 & *S. achromogenes ATCC 12767 \\
\hline $\begin{array}{l}\text { Rectiflexibiles, } \\
\text { Red/violet }\end{array}$ & $\uparrow S$. venezuelae CUB 104 & \\
\hline $\begin{array}{l}\text { Retinaculiaperti, } \\
\text { Red/violet }\end{array}$ & S. virginiae ATCC 13161 & $\uparrow$ S. fradiae CUB 305 \\
\hline Spirales, White & $\begin{array}{l}* S \text {. albus } \mathrm{G} \\
* S . \text { albus } \mathrm{P} \text { CMI } 52766 \\
\dagger S . \text { rimosus } 2251 \\
\dagger S . \text { rimosus NRRL } 2234\end{array}$ & $\begin{array}{l}* S . \text { albus A138 (Lacey) } \\
* S . \text { albus A343 (Lacey) } \\
* S . \text { albus A505 (Lacey) } \\
\dagger S . \text { albus A647 (Lacey) } \\
+S . \text { rimosus ATCC } 14827 \\
\dagger S . \text { rimosus } 2249 \\
\uparrow S . \text { rimosus } 2252\end{array}$ \\
\hline Spirales, Yellow & & *S. varsoviensis CUB 308 \\
\hline Spirales, Grey & $\begin{array}{l}\dagger S . \text { coelicolor A3(2) } \\
\text { 'S. hygroscopicus' IMET } 20664 \\
\text { S. lividans } 66 \\
\dagger S . \text { parvulus ATCC } 12434\end{array}$ & $\begin{array}{l}\text { S. matensis ISP } 5188 \\
\text { S. violaceoruber S199 (Bradley) } \\
\text { S. violaceoruber K673 (Kutzner) }\end{array}$ \\
\hline Spirales, Blue/green & $\begin{array}{l}\text { S. azureus ATCC } 14921 \\
\text { S. viridochromogenes CUB } 539 \\
\text { S. viridochromogenes CUB } 608\end{array}$ & $\begin{array}{l}\text { S. viridochromogenes } 93 \\
\text { (Lechevalier) }\end{array}$ \\
\hline Spirales, Red/violet & $\dagger$ †. erythreus CUB 92 & \\
\hline
\end{tabular}

* These strains contain site-specific endodeoxyribonucleases (Chater, 1978a; E. Clare \& K. F. Chater, unpublished data; Arrand et al., 1978; J. R. Arrand, P. A. Myers \& R. J. Roberts, personal communication).

$\uparrow$ These strains lacked detectable site-specific endodeoxyribonucleases (in single extractions using coliphage $\lambda$ DNA as substrate; K. F. Chater \& E. Clare, unpublished data).

restriction being accounted for by undermodification of the progeny DNA molecules in cells where the initial infection had escaped restriction. However, for $S$. coelicolor (Müller) we have not been able to demonstrate the involvement of restriction, since a cell-free extract contained no detectable restriction endonuclease activity on $\lambda$ DNA; an R4 mutant (R4G2) with increased in vivo susceptibility to modification in the S. albus $\mathrm{P}$ and S. albus $\mathrm{G}$ systems (see below, and Chater \& Carter, 1978) did not show increased e.o.p. on $S$. coelicolor (Müller) compared with wild-type R4 phage; and an R4 mutant with high e.o.p. on $S$. coelicolor (Müller) was unaffected in its responses to restriction by $S$. albus G or $S$. albus $\mathrm{P}$ (data not shown). Possibly the adaptation of R4 to $S$. coelicolor (Müller) is due to a simple kind of host-range mutation affecting adsorption efficiency.

\section{Restriction of $\mathrm{R} 4$ by S. albus $\mathrm{G}$}

Although R4 formed plaques efficiently on J1074, it normally gave no plaques at all on wild-type $S$. albus $\mathrm{G}$, the restriction-proficient strain from which $\mathrm{J} 1074$ was derived. R4 was then propagated on an independent restrictionless mutant (sal-40) of S.albus G which (unlike J1074) retained modification activity (Chater \& Wilde, 1980) in the expectation that modified phage would be obtained, which should then have a high e.o.p. on wild-type S. albus G. Instead, an e.o.p. of about $10^{-6}$ was obtained. Phages from five such plaques 
Table 3. Restriction-modification of $\mathrm{R} 4$ and its derivatives by

S. albus $\mathrm{G}$ strains

E.o.p. values on $S$. albus $\mathrm{G}$ were determined after pregrowth of the various $\mathrm{R} 4$ derivatives on S. albus $\mathrm{G}$ wild-type (restriction and modification proficient, i.e. $\mathrm{R}^{+} \mathbf{M}^{+}$), J1074 (S. albus $\mathrm{G} \mathrm{R}^{-} \mathrm{M}^{-}$) or sal-40 (S. albus G R-M ${ }^{+}$; Chater \& Wilde, 1980). R4G1 to R4G5 were obtained independently from single plaques on $S$. albus $\mathbf{G}\left(\mathbf{R}^{+} \mathbf{M}^{+}\right)$of $\mathbf{R} 4$ last grown on sal-40 (see text).

\begin{tabular}{|c|c|c|c|}
\hline \multirow[b]{2}{*}{$\begin{array}{c}\text { R4 derivative } \\
\text { used }\end{array}$} & \multicolumn{3}{|c|}{${ }^{*}$ E.o.p. on $S$. albus $\mathrm{G}$} \\
\hline & $\begin{array}{c}\text { Last host } \\
\text { J1074 }\left(\mathbf{R}^{-} \mathbf{M}^{-}\right)\end{array}$ & $\begin{array}{c}\text { Last host } \\
\text { sal-40 }\left(\mathbf{R}-\mathbf{M}^{+}\right)\end{array}$ & $\begin{array}{c}\text { Last host } \\
\text { S. albus } \mathrm{G}\left(\mathrm{R}^{+} \mathrm{M}^{+}\right)\end{array}$ \\
\hline $\mathrm{R} 4$ & $<1 \times 10^{-9}$ & $c a 1 \times 10^{-6}$ & - \\
\hline R4G1 & $1 \times 10^{-5}$ & $2 \times 10^{-2}$ & $1 \times 10^{-1}$ \\
\hline R4G2 & $1 \times 10^{-5}$ & $5 \times 10^{-1}$ & $7 \times 10^{-1}$ \\
\hline R4G3 & $7 \times 10^{-5}$ & $\mathrm{NT}$ & $1 \times 10^{0}$ \\
\hline R4G4 & $8 \times 10^{-6}$ & NT & $6 \times 10^{-1}$ \\
\hline R4G5 & $5 \times 10^{-5}$ & NT & $1 \times 10^{0}$ \\
\hline
\end{tabular}

NT, Not tested. $\quad *$ Assuming an e.o.p. of $10^{\circ}$ on $\mathrm{J1074.}$

obtained independently on S. albus G were found to give high e.o.p. on both S. albus G and its restrictionless derivatives. The subsequent e.o.p. of two of these phages was tested on S. albus G, and depended upon the modification status of their last host (Table 3). Thus, high e.o.p. on $S$. albus $\mathrm{G}$ was always obtained after propagation of the phages on modification-proficient strains, but after their propagation on a modification-defective S. albus G mutant (e.g. J1074) the e.o.p. on S. albus $\mathrm{G}$ fell to about $10^{-5}$. We concluded that these phage derivatives were mutants (which we termed R4G) affected in their SalGI restriction-modification sensitivity.

\section{In vitro cleavage of $\mathrm{R} 4$ and $\mathrm{R} 4 \mathrm{G} 2$ DNA by SalGI}

Since the restriction-deficient mutant J1074 lacks the endonuclease SalGI present in the restriction-proficient parent strain (Chater \& Wilde, 1976), we concluded that SalGI was the agent of R4G restriction in $S$. albus $\mathrm{G}$. In confirmation of this, DNA isolated from R4G2 grown on S. albus G (and therefore modified) was not cleaved by SalGI in vitro, whereas that isolated from either R4 or R4G2 grown on a non-modifying host was cleaved into more than 30 fragments (Fig. 5). No differences in the R4 or R4G2 cleavage patterns were detected on agarose gels, though it was not excluded that there might be differences among the lower molecular weight fragments. Microdensitometry of a number of gels showed that the band of highest molecular weight $\left(3.4 \times 10^{6}\right)$ was present in variable, but always less than equimolar, amounts and that the brighter this band, the fainter were two other bands $\left(1.97 \times 10^{6}\right.$ and $\left.1.45 \times 10^{6}\right)$. This may indicate that the two smaller bands are the ends of the linear phage DNA molecule and that these [as in coliphage $\lambda$ and 886 DNA (Kaiser \& Wu, 1968) and Streptomyces phage $\phi C 31$ DNA (Sladkova et al., 1977)] have complementary singlestranded extensions allowing hydrogen bonding between two fragments. This is assumed to be the case in the summing of all the fragment molecular weights to obtain an estimated molecular weight for R4 DNA $\left(30.02 \times 10^{6}\right.$; Fig. 5). The mean frequency of SalGI sites in this DNA is about one per 1.35 kilobases. A similar high frequency of SalGI target sites was seen for DNA of the virulent phage VP12 (Chater \& Wilde, 1980) and, like VP12 DNA, R4 DNA had a high (67 mol \%) content of guanosine plus cytosine, based on its buoyant density in $\mathrm{CsCl}$ density gradients (Fig. 6). 
A

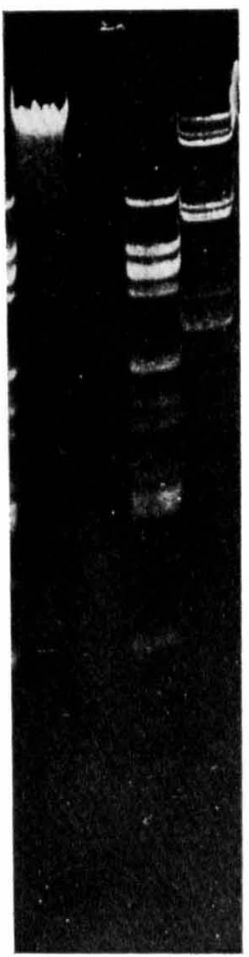

D E

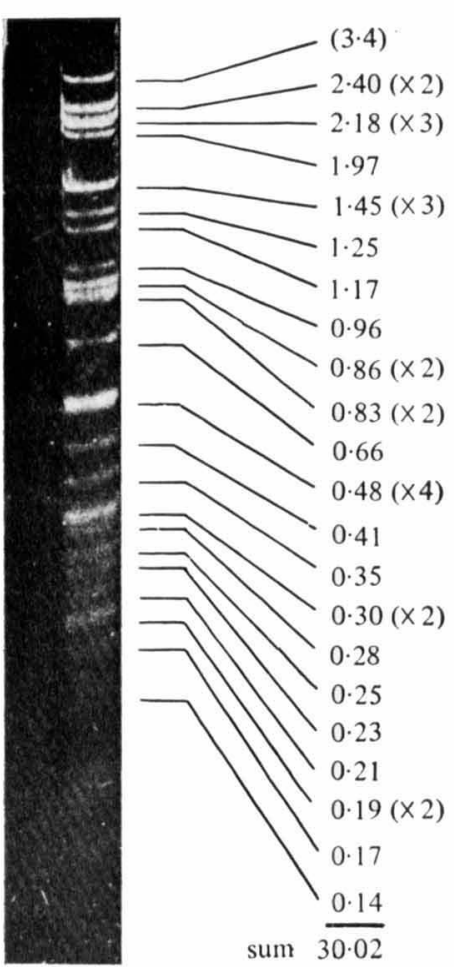

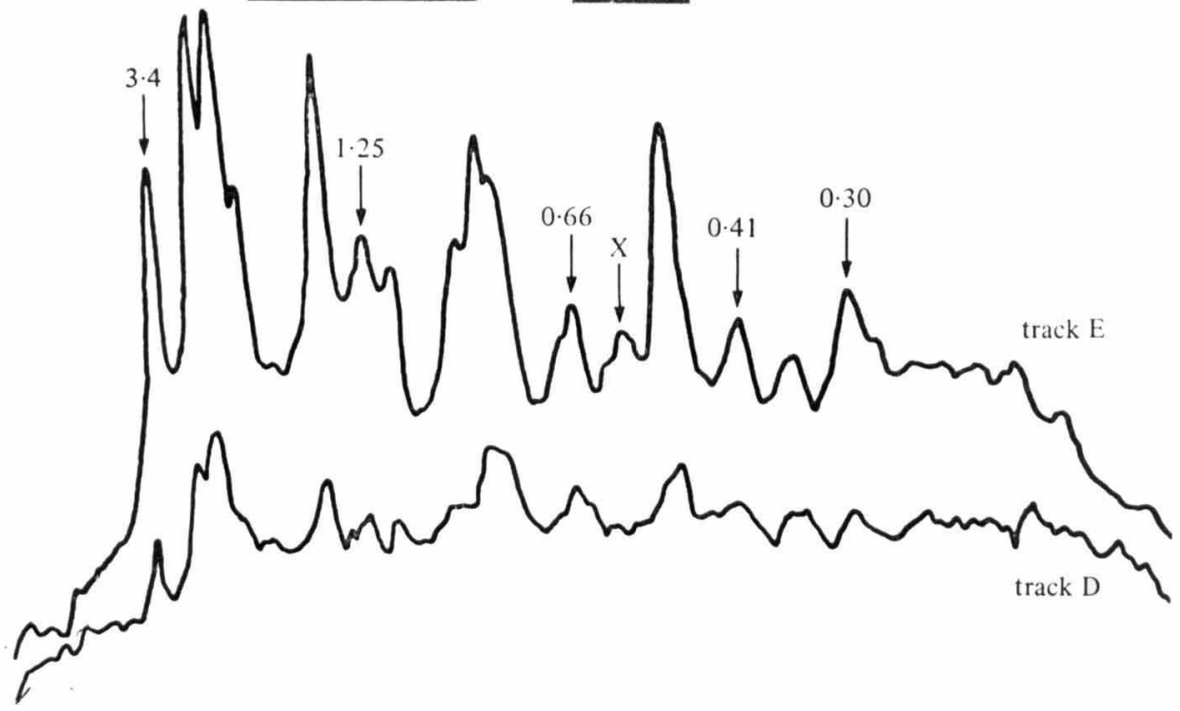

Fig. 5. Cleavage of DNA from various R4 preparations by SalGI. About $1 \mu \mathrm{g}$ DNA prepared from R4 propagated on a non-modifying host (tracks B and E) or from R4G2 propagated on a modifying host (track A) or a non-modifying host (track D; less DNA used) was incubated with $\mathrm{SalGI}$, electrophoresed in $1.4 \%(\mathrm{w} / \mathrm{v})$ agarose, stained with ethidium bromide, and photographed under irradiation at $365 \mathrm{~nm}$. Electrophoresis was from top to bottom. Molecular weights $\left(\times 10^{-6}\right)$ were estimated by comparison with standards (track C) obtained by digestion of $\lambda$ DNA with SalPI (Chater, 1977). Relative molar amounts of fragments in each band were estimated by microdensitometry (lower figures). In calculating the total molecular weight, the fragment of $3.4 \times 10^{6}$ molecular weight is excluded (see Results). The microdensitometer tracings shown are of tracks $\mathbf{D}$ and E. Molecular weights $\left(\times 10^{-6}\right)$ are given for some peaks on the tracings in order to facilitate cross-reference with the gels. The peak marked $X$ is an artifact caused by a scratch on the negative. 


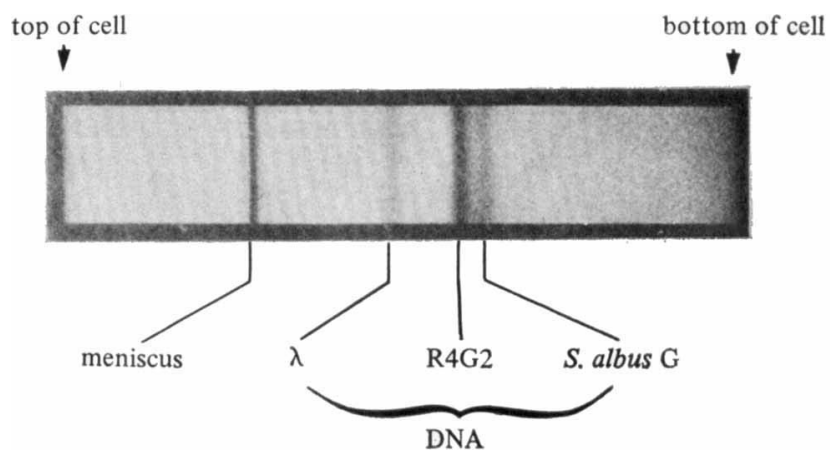

Fig. 6. $\mathrm{CsCl}$ density gradient centrifugation of DNA from R4G2. The relative position in a $\mathrm{CsCl}$ density gradient (at equilibrium) of DNA of R4G2 and two standards (DNA of phage $\lambda$ and of $S$. albus $\mathrm{G})$ was recorded by photographing under ultraviolet light $(260 \mathrm{~nm})$ during centrifugation on a Spinco Model E centrifuge.

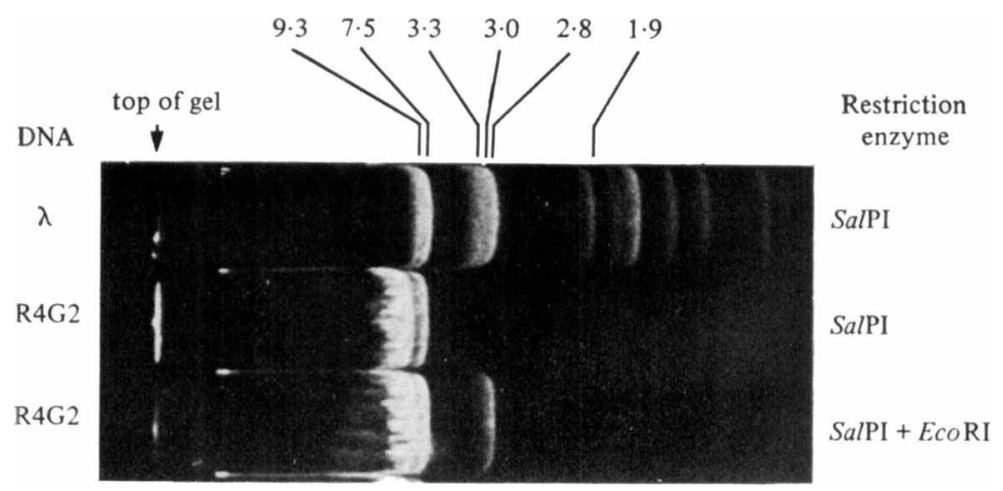

Fig. 7. Agarose gel electrophoresis of R4G2 DNA cleaved by SalPI and EcoRI. Molecular weights $\left(\times 10^{-6}\right)$ of standards are given. Electrophoresis was from left to right.

\section{Cleavage of R4 DNA by other restriction enzymes}

R4 DNA was not cleaved at all by BamHI or HindIII but was cleaved at single sites by EcoRI (4.5 kilobases from one end of the molecule) and SalPI (12.75 kilobases from one end of the molecule) ( $\mathrm{SalPI}$ is an isoschizomer of Pst I; Chater, 1977). Figure 7 shows that the two enzymes cut at opposite ends of the molecule, since the 12.75 kilobase SalPI fragment is not reduced in size after cleavage with EcoRI.

\section{Restriction of $\mathrm{R} 4 \mathrm{G}$ mutants by two $S$. rimosus strains}

Unmodified R4 (i.e. last grown on J1074) gave quite high e.o.p. on two S. rimosus strains (2251 and NRRL 2234: Table 1). In the case of 2251 (NRRL 2234 was not tested), this was not changed by passage through the $S$. rimosus strains, suggesting that restriction and modification of R4 did not take place (Table 4). Surprisingly, R4G2 phage had a 10-fold lower e.o.p. on both strains, and on further examination this proved to depend upon the last host; for example, prior growth on 2251 gave a relatively high e.o.p. on 2251, but subsequent passage through $\mathrm{J} 1074$ resulted in a return to the lower e.o.p. on 2251. Similar results were obtained with NRRL 2234 (data not shown). Thus the R4G2 mutant, but not its parental phage R4, was subject to host-controlled restriction and modification in the two $S$. rimosus strains. Identical specificity of the two systems was established by finding that when 2251 was the last host a relatively high e.o.p. was obtained on NRRL 2234, and vice versa (Table 5). Further studies were therefore confined to 2251. 
Table 4. Restriction-modification of $\mathrm{R} 4 \mathrm{G} 2$ by S. rimosus 2251

$\begin{array}{lcc}\text { Previous hosts (in sequence) } & \text { R4 } & \text { RE.o.p. on } 2251 \\ \text { J1074 } & 3 \times 10^{-1} & 2 \times 10^{-2} \\ \mathrm{~J} 1074,2251 & 3 \times 10^{-1} & 2 \times 10^{-1} \\ \mathrm{~J} 1074,2251, \mathrm{~J} 1074 & 3 \times 10^{-1} & 2 \times 10^{-2} \\ * \text { Assuming an e.o.p. of } 10^{\circ} \text { on J1074. }\end{array}$

Table 5. Shared specificity in the restriction-modification systems of S. rimosus 2251 and S. rimosus NRRL 2234

\begin{tabular}{lcc}
$\begin{array}{c}\text { Previous hosts (in } \\
\text { sequence) of R4G2 }\end{array}$ & *E.o.p. on & *E.o.p. on \\
NRRL 2234 & 2251 \\
NRRL 2234, J1074 & $3 \times 10^{-2}$ & $4 \times 10^{-2}$ \\
NRRL 2234, NRRL 2234 & $3 \times 10^{-1}$ & $3 \times 10^{-1}$ \\
2251, J1074 & $3 \times 10^{-2}$ & $4 \times 10^{-2}$ \\
2251, 2251 & $3 \times 10^{-1}$ & $3 \times 10^{-1}$ \\
\multicolumn{2}{c}{$*$ Assuming an e.o.p. of $10^{\circ}$ on J1074. }
\end{tabular}

The e.o.p. on 2251 of the four other R4G mutants mentioned earlier was also tested, and in all cases it was 10- to 100-fold lower than was obtained with R4. Two of the phages (R4G1 and R4G4) were examined further. In the case of R4G4, which had the lowest initial e.o.p. $\left(1 \times 10^{-3}\right)$ on 2251 , subsequent behaviour was identical to that described for $\mathrm{R} 4 \mathrm{G} 2$. In the case of R4G1, however, a plaque taken from the first plating on 2251 subsequently proved insensitive to 2251 , like the parental phage R4. Since the other R4G characteristics (restriction-modification characteristics in the S.albus $\mathrm{G}$ and S. albus $\mathrm{P}$ systems; Table 5 and Chater \& Carter, 1978) remained unchanged in this derivative of R4G1 (i.e. it had not reverted from R4G to R4), the simplest (but untested) explanation would be that a mutant lacking any target site for the 2251 restriction system had been selected.

Despite the anomalous behaviour of R4G1, it therefore appears that mutations of R4 leading to the R4G phenotype invariably confer sensitivity to a restriction-modification system present in two $S$. rimosus strains. However, attempts to find type II restriction enzyme activity in cell-free extracts of both strains failed, using either $\lambda$ DNA or unmodified R4G2 DNA (from phage grown on J1074) as the substrate.

\section{DISCUSSION}

Four groups of heteroimmune temperate bacteriophages attacking Streptomyces coelicolor A3(2) have been discovered and they share certain features. VP5, S14 and R4 are fairly similar to lambda phage in morphology and dimensions (Fig. 2; Dowding \& Hopwood, 1973; C. Stuttard, unpublished data) and all are similar in the molecular weights of their DNA (Chater, 1978b). Their one-step growth curves are almost superimposable. However, R4 differs from the other groups of phages in several ways. It has unusually high divalent cation requirements for optimal adsorption; it is unable to form plaques above $34.5{ }^{\circ} \mathrm{C}$; clear-plaque mutants are very rare; and, most importantly, it forms plaques on a wide range of Streptomyces hosts, and lysogenizes many of them (though it does not appear to lysogenize $S$. coelicolor).

Thanks to its wide host-range, R4 is proving useful in studies of several Streptomyces restriction-modification systems. We have previously described its sensitivity to the SalPI system of S. albus P (Chater \& Carter, 1978) and here we have shown that it is also subject 
to restriction-modification systems operating in S. albus G (the SalGI system; Chater \& Wilde, 1976) and in two S. rimosus strains. In none of the cases was restriction initially obvious. For the two $S$. albus strains, modification of phages which had evaded the initial restriction was apparently so inefficient that plaques were formed only by phage mutants. In the case of $S$. albus $\mathrm{P}$ these were invariably mutants (R4P) lacking the single SalPI target site (Chater \& Carter, 1978) whereas in the case of $S$. albus $G$ the mutants (R4G) were apparently altered in their ability to be modified, for reasons that are not understood. With many R4G mutants, modification is also more efficient in the SalPI system, and these mutants reveal 'classical' patterns of restriction-modification in the two systems (Table 3; Chater \& Carter, 1978). R4G also reveals restriction-modification systems of shared specificity in two $S$. rimosus strains, but here the wild-type R4 phage, instead of being more sensitive to restriction than $\mathrm{R} 4 \mathrm{G}$, is unrestricted. This might be due to the presence of a restriction site in R4G DNA which is absent from R4 DNA (if, for example, R4G mutants contained inserted DNA absent from the parental phage; however, no differences in restriction enzyme cleavage patterns have been noted between R4G2 DNA and R4 DNA). Another testable possibility is that R4 might specify a non-site-specific modification system that alters SalGI and SalPI target sites in such a way that the SalGI and SalPI modification enzymes are prevented from effectively carrying out the specific modification needed for protection against the respective restriction enzymes. This same non-specific system might protect R4 DNA against the $S$. rimosus restriction enzyme. Thus the loss of non-specific modification would result in the acquisition of sensitivity to the $S$. rimosus system.

Further study of these interesting interactions between R4 and various restrictionmodification systems may lead both to insights into the biological roles of restrictionmodification and to a better understanding of factors affecting host-range in bacteriophages.

Recent work has lead to real hopes that plasmid vectors for the cloning of DNA fragments into Streptomyces will soon be available. For various purposes, bacteriophage vectors may also be of value. R4 appears to offer certain advantages here: it is temperate; it has a wide host-range; its DNA can quite easily be obtained in reasonable quantity; and it has single target sites for two restriction enzymes, EcoRI and Pst ( $\equiv$ SalPI), widely used in DNA cloning in other bacteria. A critical requirement for this use of R4 is the development of a transfection system. The polyethylene glycol-dependent system used by Bibb et al. (1978) to transform Streptomyces protoplasts with SCP2* plasmid DNA has also proved effective in transfection with VP5 DNA (Chater, 1978b), and has recently been extended to several other phages including R4 (J. E. Suarez, unpublished results).

We thank Kitty Plaskitt for carrying out electron microscopy, Eddie Clare for analysing cell-free extracts of various wild-type strains for restriction enzymes, Roger Hull for carrying out Model E centrifugations, Lynn Wilde for expert technical assistance, and David Hopwood for critically reading the manuscript.

\section{REFERENCES}

Arai, T., Kuroda, S. \& Mikami, Y. (1976). Classification of actinomycetes with respect to antibiotic production. In Actinomycetes - The Boundary Microorganisms, pp. 543-651. Edited by T. Arai. Tokyo \& Singapore: Toppan Co.

Arrand, J. R., Myers, P. A. \& Roberts, R. J. (1978). A new restriction endonuclease from Streptomyces albus G. Journal of Molecular Biology 118, 127-135.

Bibb, M. J., Freeman, R. F. \& Hopwood, D. A. (1977). Physical and genetical characterisation of a second sex factor, SCP2, for Streptomyces coelicolor A3(2). Molecular and General Genetics 154, 155-166.

Bibb, M. J., Ward, J. M. \& Hopwood, D. A. (1978). Transformation of plasmid DNA into Streptomyces at high frequency. Nature, London 274, 398400.

Chater, K. F. (1977). A site-specific endodeoxyribonuclease from Streptomyces albus CMI52766 sharing site-specificity with Providencia stuartii endonuclease Pst I. Nucleic Acids Research 4, 1989-1998.

ChATER, K. F. (1978a). Restriction in Streptomyces. 
In Nocardia and Streptomyces, Proceedings of the International Symposium on Nocardia and Streptomyces, pp. 303-311. Edited by M. Mordarski, W. Kurylowicz \& J. Jeljaszewicz. Stuttgart: G. Fischer Verlag.

ChATER, K. F. (1978b). Recent developments in Streptomyces genetics. In Proceedings of the Third International Symposium on Genetics of Industrial Microorganisms, (in the Press). Edited by $\mathbf{O}$. K. Sebek. Washington: American Society of Microbiology.

Chater, K. F. \& CARTer, A. T. (1978). Restriction of a bacteriophage in Streptomyces albus $\mathrm{P}$ (CMI 52766) by endonuclease SalPI. Journal of General Microbiology 109, 181-185.

Chater, K. F. \& Sykes, K. I. (1976). Induction of prophage during germination and sporulation in Streptomyces coelicolor. In Spore Research, 1976, vol. 1, pp. 131-142. Edited by A. N. Barker, J. Wolf, D. J. Ellar, G. J. Dring \& G. W. Gould. London and New York: Academic Press.

Chater, K. F. \& WiLde, L. C. (1976). Restriction of a bacteriophage of Streptomyces albus G involving endonuclease SalI. Journal of Bacteriology 128, 644-650.

Chater, K. F. \& WiLde, L. C. (1980). Streptomyces albus $\mathrm{G}$ mutants defective in the $\mathrm{SalGI}$ restrictionmodification system. Journal of General Microbiology 116 (in the Press).

DowDING, J. E. (1972). Studies on bacteriophages of Streptomyces coelicolor. Ph.D. Thesis, University of East Anglia.

Dowding, J. E. (1973). Characterization of a bacteriophage virulent for Streptomyces coelicolor A3(2). Journal of General Microbiology 76, 163176.

Dowding, J. E. \& Hopwood, D. A. (1973). Temperate bacteriophages for Streptomyces coelicolor
A3(2) isolated from soil. Journal of General Microbiology 78, 349-359.

Hershey, A. D. \& Chase, M. (1952). Independent function of viral protein and nucleic acid in growth of bacteriophage. Journal of General Physiology 36, 39-56.

Hopwood, D. A. (1967). Genetic analysis and genome structure in Streptomyces coelicolor. Bacteriological Reviews 31, 373-403.

Hopwood, D. A., Chater, K. F., Dowding, J. E. \& Vivian, A. (1973). Recent advances in Streptomyces coelicolor genetics. Bacteriological Reviews 37, 371-405.

KAISER, A. D. \& Wu, R. (1968). Structure and function of DNA cohesive ends. Cold Spring Harbor Symposia on Quantitative Biology 33, 729-734.

Kellenberger, E. \& Edgar, R. S. (1971). Structure and assembly of phage particles. In Bacteriophage Lambda, pp. 195-210. Edited by A. D. Hershey. New York: Cold Spring Harbor Laboratory.

Lomovskaya, N. D., Emeljanova, L. K. \& AliKHANIAN, S. I. (1971). The genetic location of prophage on the chromosome of Streptomyces coelicolor. Genetics 68, 341-347.

Lomovskaya, N. D., Mkrtumian, N. M., GostimsKAYA, N. L. \& Danilenko, V. N. (1972). Characterisation of temperate actinophage $₫ \mathrm{C} 31$ isolated from Streptomyces coelicolor A3(2). Journal of Virology 9, 258-262.

MacHattie, L. A. \& Thomas, C. A. (1968). Viral DNA molecules. In Handbook of Biochemistry, pp. H3-H7. Edited by H. A. Sober. Cleveland, Ohio: Chemical Rubber Company.

Sladkova, I. A., Lomovskaya, N. D. \& ChINENOVA, T. A. (1977). The structure and size of the genome of actinophage $ø \mathrm{C} 31$ of Streptomyces coelicolor A3(2). Genetika 13, 342-344. 